An Assessment of sustainable housing affordability using a multiple criteria decision making method

Mulliner, Emma and Smallbone, Kieran and Maliene, Vida 2012 MIMS EPrint: 2012.53

Manchester Institute for Mathematical Sciences

School of Mathematics

The University of Manchester

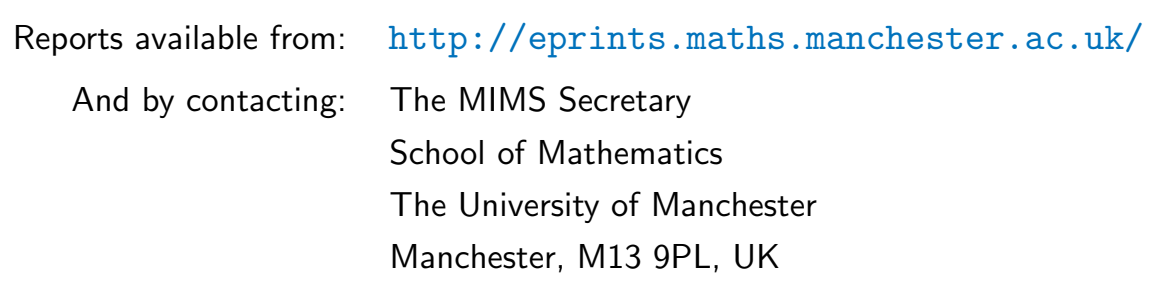




\title{
An Assessment of Sustainable Housing Affordability Using a Multiple Criteria Decision Making Method
}

\author{
Emma Mulliner ${ }^{1}$, Kieran Smallbone ${ }^{2}$, Vida Maliene ${ }^{3^{*}}$ \\ ${ }^{1}$ School of the Built Environment, Liverpool John Moores University, Henry Cotton Building, 15-21 \\ Webster Street, Liverpool, UK, L3 2ET. \\ ${ }^{2}$ Manchester Interdisciplinary Centre, The University of Manchester, 131 Princess Street \\ Manchester, UK, M1 7DN. \\ ${ }^{3}$ School of the Built Environment, Liverpool John Moores University, Cherie Booth, Byrom Street, \\ Liverpool, UK, L3 $3 \mathrm{AF}$. \\ *-Corresponding author
}




\title{
An Assessment of Sustainable Housing Affordability Using a Multiple Criteria Decision Making Method
}

\begin{abstract}
Housing affordability is a complex issue that must not only be assessed in terms economic viability. In order to increase quality of life and community sustainability the environmental and social sustainability of housing must also be taken into consideration.

The paper considers the application of a methodology that can be applied to assess the affordability of different housing locations in a sustainable manner, taking into account a range of economic, environmental and social criteria. The COPRAS method of multi-criteria decision making (MCDM) is selected and applied to three residential areas as an example of how sustainable housing affordability can be assessed using a MCDM method. The outcome of the study reveals that considering a range of social and environmental criteria can greatly affect the calculation of an areas affordability, in comparison to focusing solely on financial attributes. COPRAS was found to be an effective method for the assessment and could be applied in other regions or internationally.
\end{abstract}

Keywords: Affordability, Affordable housing, COPRAS, Multiple criteria decision making (MCDM), Sustainable communities.

\section{Introduction}

Currently affordable housing and sustainable development are major challenges facing the UK and many other countries across the globe. Sustainability and affordability concerns are now often discussed mutually and are recognised as being important to one another $[1,2,3,4,5,6]$; namely, affordable housing ought to be located within sustainable mixed communities and sustainable communities must provide affordable housing products. Accordingly, it is essential that affordability and sustainability issues are tackled simultaneously. However, housing affordability is frequently defined and assessed only in terms of economic viability. Other important issues, such as sustainability, housing location and quality are sometimes overlooked.

Comparing the relationship between housing expenditure and household income is the most common way to define and measure housing affordability internationally [7, 8, 9]. Such an assessment relies on a 'rule of thumb' which suggests that any household spending more than a certain proportion of its income on housing costs lives in unaffordable housing. This approach stems from initial studies on housing affordability, which date back to 19th century studies of the household budget, which commonly equated "one week's pay for one month's rent" [7, p. 471]. Housing cost to income ratios are extensively applied to measure affordability in the UK and other European countries, the U.S., Canada, Australia, New Zealand and China [10, 11, 12, 13, 14]. The ratio approach appears to be ubiquitously and often indisputably adopted in international housing policies, within developed countries, to measure housing affordability. This is not surprising since it has the advantage of being easy to compute as it only relies on a few variables which are usually easily accessible. However, the housing expenditure to income ratio 
has been subject to criticism by several authors [7, 13, 14, 15]. This is primarily due to its arbitrary and normative nature $[7,13,14,16]$ and inability to account for issues such as housing quality [15].

In contrast to the conventional way of conceiving and measuring affordability, Stone [13, 14] recognises that housing affordability is not separable from housing standards. Accordingly Stone [13] introduced the 'shelter poverty' measure which attempts to assess affordability by taking into account the adequacy of household income to cover both housing costs and other necessary non-housing costs, thus seeking to maintain an adequate standard of living. This measure therefore focuses on the residual income remaining after housing costs have been met. However, the residual approach shares some of the shortcomings of the ratio measure, such as the inability to control for housing or location quality. Bogdon and Can [15] criticised the pre existing affordability literature for focusing on house prices rather than the condition, location and neighbourhood characteristics of the housing. However, even today day the majority of tools used to assess affordability have little or no regard for housing quality, location and neighbourhood characteristics, i.e. what households get in return for what they spend on housing.

\section{Research problem}

The ODPM [5] admit that, previously, in a rush to build more homes to meet demand the government too often did not build communities. Jobs, shops and services, transport and green spaces are also important factors for creating thriving communities [5]. It is not enough to simply provide more homes, there must also be a strong focus on creating sustainable communities [3]. Sustainable communities are defined as "Places where people want to live and work, now and in the future" [4, p.56]. They should be active, inclusive and safe, well run, environmentally sensitive, well designed and built, well connected, thriving, well served and fair for everyone [4]. Building housing that is not well connected to jobs, high quality services and infrastructure can and has contributed to areas experiencing low demand and abandonment. The Housing Market Renewal Initiative was prompted by the government to tackle problems of low demand and the emergence of housing abandonment in several parts of the North and the Midlands in England. In such neighbourhoods, high levels of low demand properties, population loss and high vacancy rates created decline and deprivation [17]. These areas suffer from a lack of jobs, poor public services, crime and anti-social behaviour, with streets and parks in disrepair [5]. The traditional way of conceiving and measuring affordability (the ratio of housing costs to income) may indicate that such areas are affordable, simply because they are low-cost. However, this fails to indicate anything about the quality of the housing or the environment in which the housing is situated. Accordingly, this may be a rather simplistic and unsustainable way to view affordability.

Research undertaken by the Australian Housing and Urban Research Institute (AHURI) stresses that OECD countries are increasingly recognising the need for a broad and more encompassing understanding of housing affordability, such measures would replace simple ratio measures based on housing costs and income which cannot deal with issues such as housing adequacy, location quality and access to services [18]. Nevertheless, research by the AHURI continues to focus on housing costs and incomes [19]. This research advocates the continued use of the expenditure to income ratio due to its long tradition, ease of use and to provide continuity [18]. 
In contrast, other research conducted in Australia advocates that housing affordability must account for ancillary costs that households may face, e.g. accessing key services, facilities and employment, and the cost of electricity, gas and water [20]. It seems that a number of authors are seeking to challenge the conventional ratio standards which are frequently used to define and assess housing affordability.

It has been suggested that the traditional way of defining and measuring housing affordability (the ability of household income to cover housing costs) may be too limited; the interaction between housing and location is thought to provide a more meaningful measure of housing affordability [21]. Furthermore, Fisher et al. [22] suggest that an important aspect of housing affordability depends on the amenities based on the particular housing location, which affects the welfare of households. Their study looks at affordability in terms of a bundle of attributes an area possesses, such as school quality, job accessibility and safety. The authors assess whether accounting for the implicit prices of such attributes influences an areas affordability measure. The authors conclude that focusing on price alone may lead to inaccurate conclusions about the affordability of an area [22].

But how is the concept of affordability perceived by low and moderate income families themselves? Seelig and Phibbs [16] conducted qualitative analysis of housing affordability to understand how low-income renters understand residential affordability. They found that lowincome families often did not choose areas that had poor amenity and location measures. Thus, while cost was an essential consideration, addressing needs or preferences for dwelling features, location or proximity to services and facilities was a priority for many low income renters, even though such choices resulted in tighter household budgets and paying more for housing [16]. The research demonstrates that an array of attributes, in addition to purely economic factors, can influence a household's perception of affordability. Specifically, quality, location and access to services and facilities appear to be important considerations directly related to a household's perception of affordability.

Clearly, improving housing affordability is not the only means by which housing can become economically viable. As well as housing costs, the aforementioned literature advocates that a wider range of criteria must be taken into consideration in order to determine true housing affordability and quality of life. Such findings have motivated the authors to conduct this particular research and develop a methodology that can be used to assess the affordability of different housing locations in a sustainable manner, taking into account a range of economic, environmental and social criteria that influence both the affordability and sustainability of housing. Given the complexity of the issue under consideration, multiple criteria decision making (MCDM) appeared to be appropriate as the basis of an assessment tool for sustainable housing affordability.

Multiple criteria decision making (MCDM), often called multi criteria decision aid (MCDA) and multi criteria analysis (MCA), is a set of methods which allow the aggregation and consideration of numerous (often conflicting) criteria in order to choose, rank, sort or describe a set of alternatives to aid a decision process [23]. MCDM is suitable for the said topic as it is able to address the numerous quantitative and qualitative criteria that affect both housing affordability and sustainability, all of which can be incorporated into one evaluation process. 
There are three steps that all MCDM techniques follow [24, p. 5-6]

1. Determine relevant criteria and alternatives;

2. Attach numerical measures to the relative importance of the criteria and to the impacts of the alternative on these criteria;

3. Process the numerical values to determine a ranking of each alternative.

Step 1 can be aided by methods which assist in structuring decision making problems. For example, Kenney's value focused thinking [25] which uses hierarchical structures to build criteria, leading from primary goals to fundamental objectives, which are further broken down to specific criteria or Strategic Options Development and Analysis (SODA) which utilises cognitive mapping [26].

In order to process the numerical values (step 3) there are various different MCDM methods available, each with their own varying characteristics. Some of the most commonly used methods include the AHP [27], TOPSIS [28], PROMETHEE [29], ELECTRE [30] and COPRAS [31]. For a survey and comparison of different MCDM methods see [32], [33] and [34], although the COPRAS method is not discussed.

Several MCDM methods have been applied in property, planning and built environment related research. For example, Ball and Srinivasan [35] proposed the AHP method to aid house selection for buyers. Bender et al. [36] used the AHP to analyse the environmental preferences of homeowners in three Swiss cities, though the ELECTRE method was mentioned as a possible alternative for environmental quality problems. Johnson [37] utilised the PROMETHEE method to enable clients under the Housing Choice Voucher Program (USA) to make better decisions about neighbourhoods in which to search for housing. Natividade-Jesus et al. [38] proposed a decision support system, including the use of SAW (Simple Additive Weighting), TOPSIS and ELECTRE, in order to assist several stakeholders in making better decisions on housing evaluation; the research concluded that ELECTRE was the preferred method. Lotfi and Solaimani [39] made an assessment of urban quality of life in Iran using the AHP.

The COPRAS method in particular has been used for a variety of decision making problems found within the built environment. For example, Zavadskas et al. [40] utilised the method to assess building life cycles in order to select an optimal alternative. Zavadskas et al. [41] presented a model of housing credit access for a Lithuanian case study, which sought to determine the most rational housing investment instruments and lenders, using the COPRAS method. Kaklauskas et al. [42] applied the technique in order to design and realise efficient building refurbishment options. COPRAS has also been used in order to define the utility and market value of real estate [43]. Viteikienè and Zavadskas [44] valuated the sustainability of residential areas in Vilnius City using COPRAS. Additionally, a model for measuring sustainable city compactness has been developed based on the COPRAS method [45]. Banaitiene et al. [46] adopted COPRAS to support decision-making on a building's life cycle selection by designing alternatives of the building life cycle and evaluating their qualitative and quantitative aspects. Furthermore, SAW (simple additive weighting) and TOPSIS methods were used in order to compare and examine the effectiveness of COPRAS; the final rankings produced by the three methods were the same [46]. COPRAS, along with SAW and TOPSIS, were also used in the 
evaluation of social and economic development of Lithuanian regions [47]. Uilaityte and Martinaitis [48] sought to identify a building's optimal renovation solution, from a number of possible alternatives, using COPRAS. Furthermore, COPRAS, SAW and MEW (multiplicative exponential weighting) were applied for the purpose of selecting an appropriate one flat dwelling house, taking into account the environmental impact of its construction, financial and qualitative criteria; all three MCDM methods produced the same final ranking of alternatives [49].

The paper presents a tool that can be used to assess sustainable housing affordability, which is based on a criteria system developed by the authors and validated by professionals. A method of MCDM is utilised to carry out an initial assessment of sustainable housing affordability. The application of the MCDM method will ultimately establish the priority order (ranking) of given alternative residential areas in respect of their sustainable housing affordability. This approach will provide a full criteria analysis of the various factors that influence sustainable housing affordability.

An example of how the tool can be applied is provided in this paper using three residential areas (housing wards) in Liverpool, England as a case study (see Fig.1). Liverpool in particular was selected as a case study location because the city has a diverse and polarised housing market, with some areas experiencing low demand and housing market failure, whilst others areas have rapidly rising house prices. Such a diversity in the city's housing markets will assist in demonstrating how a full criteria analysis can better determine true housing affordability, reflecting the quality and sustainability of a housing location, rather than relying on price alone as the principal determinant of affordability. 


\section{Materials and Methods}

\subsection{Data collection}

The data collection process included the following stages: determining sustainable housing affordability criteria, determining criteria weights, selecting decision alternatives for comparison, calculating criteria values for each alternative, and finally, forming a decision-making matrix with the aforementioned data.

A two stage approach was adopted to develop the criteria system and to validate and subsequently weight such criteria. Initially, a system of criteria defining sustainable housing affordability was identified via an extensive literature review and semi-structured interviews with local authorities in Merseyside and Cheshire, England. The semi-structured interviews probed professionals on their opinion on the factors that are important to housing affordability. Furthermore, relevant literature on the subjects of housing affordability and sustainable communities was reviewed to determine attributes that influence sustainable housing affordability. A total of 20 criteria were identified. Table 1 displays the full criteria system and indicates the derivation of each criterion (i.e. literature source and/or interview process). 


\section{Table 1 here}

Subsequently, the criteria system was validated and weighted via questionnaire surveys. The 20 criteria differ according to their relative importance to sustainable housing affordability. Therefore, weighting was introduced in order to reflect the significance of the criteria. A questionnaire survey was distributed to experts in order to elicit data on the importance of the sustainable housing affordability criteria. The survey was conducted with 65 housing and planning experts in North West England. These experts, basing their answers on their knowledge, experience and perception, ranked the sustainable housing affordability criteria on a scale of importance ranging from 1 to 10 , where a ranking of 1 meant "not important at all" and a ranking of 10 meant "most important". This allowed criteria to be validated, or even excluded, from the proposed sustainable housing affordability criteria system. The mean ranking of importance obtained for each criterion was converted into a weight by dividing by the sum of mean scores and multiplying by 100 . As such, we ensure the total of all weights is $100 \%$. The mean scores of importance obtained via the questionnaire process and the subsequent weights for the criteria are displayed in Table 1.

Three alternative residential areas (housing wards) in Liverpool, England were selected for comparison purposes. As the presented methodology is a pilot exercise only a small data set was used at this stage. The three alternative case study areas were randomly selected from the 30 housing wards located within Liverpool. The first alternative is Princes Park $\left(A_{1}\right)$, the second alternative is Childwall $\left(A_{2}\right)$ and the final alternative is Allerton and Hunts Cross $\left(A_{3}\right)$ (shown in Fig.1).

Criteria values were determined using secondary sources, such as local authority and government publications. GIS (geographic information systems) mapping, provided by the local authority (Liverpool City Council), was also used in order to assist in determining ease of access to amenities and facilities for each case study area (e.g. for criterion 7 through to criterion 14). Some examples of how criteria values were calculated are as follows: 
Criterion 1 (house prices in relation to income) was assessed by equating average house price to income ratios. A ratio is calculated by dividing house price by household income. The average income for North West England ( $£ 33,263$ for 2010) was used to compute the ratios. The ratio was calculated for four tenures (detached/semi-detached/terraced/flat) and then an average house price to income ratio was obtained for each alternative area. For this case study the values were calculated as follows:

\begin{tabular}{lcccccc}
\hline & \multicolumn{2}{c}{ Princes Park } & \multicolumn{2}{c}{ Childwall } & \multicolumn{2}{c}{ Allerton \& Hunts Cross } \\
\hline Tenure & $\begin{array}{c}\text { Average } \\
\text { Price }\end{array}$ & Ratio & $\begin{array}{c}\text { Average } \\
\text { Price }\end{array}$ & Ratio & $\begin{array}{c}\text { Average } \\
\text { Price }\end{array}$ & Ratio \\
& $\begin{array}{l}£ 263,333 \\
\text { Detached }\end{array}$ & 7.9 & $£ 269,321$ & 8.1 & $£ 397,450$ & 11.9 \\
Semi & $£ 124,278$ & 3.7 & $£ 183,985$ & 5.5 & $£ 186,563$ & 5.6 \\
Terraced & $£ 70,817$ & 2.1 & $£ 134,433$ & 4 & $£ 117,368$ & 3.5 \\
Flat & $£ 78,843$ & 2.4 & $£ 137,967$ & 4.1 & $£ 117,150$ & 3.5 \\
& & Average $=4$ & & Average $=5.4$ & & Average $=6.1$ \\
\hline
\end{tabular}

(House prices sourced from: www.rightmove.co.uk)

Criterion 2 (rental costs in relation to income) was assessed by calculating the average percentage (\%) of income spent on rent. This was equated for 1, 2, 3 and 4 bedroom properties and an average value was then concluded. To compute this data, the average annual income figure for North West England (£33,262 for 2010) was used to determine a monthly household income figure $(£ 2,560)$. Using this average monthly household income figure the average percentage of income spent on rental costs was calculated as follows:

\begin{tabular}{ccccccc}
\hline & \multicolumn{2}{c}{ Princes Park } & \multicolumn{2}{c}{ Childwall } & \multicolumn{2}{c}{ Allerton \& Hunts Cross } \\
\hline Beds & $\begin{array}{c}\text { Average } \\
\text { Rent }\end{array}$ & $\begin{array}{c}\text { \% income } \\
\text { spent }\end{array}$ & $\begin{array}{c}\text { Average } \\
\text { Rent }\end{array}$ & $\begin{array}{c}\text { \% income } \\
\text { spent }\end{array}$ & $\begin{array}{c}\text { Average } \\
\text { Rent }\end{array}$ & $\begin{array}{c}\text { \% income } \\
\text { spent }\end{array}$ \\
\hline 1 & $£ 454$ & 17.7 & $£ 486$ & 19 & $£ 514$ & 20.1 \\
2 & $£ 565$ & 22.1 & $£ 594$ & 23.2 & $£ 673$ & 26.3 \\
3 & $£ 757$ & 29.6 & $£ 698$ & 27.3 & $£ 714$ & 27.9 \\
4 & $£ 814$ & 31.8 & $£ 955$ & 37.3 & $£ 1,093$ & 42.7 \\
& & Average $=25.3$ & & Average $=26.7$ & & Average $=29.3$ \\
\hline
\end{tabular}

(Rental costs sourced from: www.nestoria.co.uk)

Criterion 6 (safety/crime) was assessed using crime statistics from Liverpool City Council's (LCC) ward profiles, which provide economic and social data concerning all of Liverpool's housing wards. The crime rate (all crime per 1,000 persons) for each neighbourhood area was compared against the City average and a corresponding score was established (see below).

Valuation of criterion 6 - safety (crime):

\begin{tabular}{lc}
\hline Crime rate & Associated score \\
\hline Well above city average & 5 \\
Above city average & 4 \\
Average & 3 \\
Below city average & 2 \\
Well below city average & 1 \\
\hline
\end{tabular}


Thus, for this case study the values for criterion 6 were calculated as follows (data on Liverpool is provided as an average benchmark):

\begin{tabular}{ccc}
\hline Alternative & Crime rate & Associated score \\
\hline Liverpool (average benchmark) & 48.8 & N/A \\
Princes Park & 61.7 & 4 \\
Childwall & 21.3 & 1 \\
Allerton \& Hunts Cross & 26.2 & 1 \\
\hline
\end{tabular}

Criterion 7 (access to employment) was assessed in two parts: part A - distance to employment opportunities and part B - employment deprivation. Distance to employment opportunities was calculated for each neighbourhood using maps provided by LCC which show key employment sites and access boundaries (i.e. access within 15 minutes, access within 30 minutes). Employment deprivation was calculated using Job Seekers Allowance (JSA) data which shows the percentage claimants within a neighbourhood area. JSA is a benefit paid to people who are unemployed, but who are available for, and actively seeking work. The national average JSA claim rate was used as a benchmark and then data for each neighbourhood area was assessed against it and given an associated score (see below). The scores for part A and part B were then combined in order to obtain a final value for criterion 7.

Valuation of criterion 7 part A - distance to employment opportunities:

\begin{tabular}{lc}
\hline Distance & Associated score \\
\hline High - key employment site within 15 minutes by public transport & 3 \\
Moderate - key employment site within 30 minutes by public transport & 2 \\
Low - key employment site over 30 minutes away by public transport & 1 \\
\hline
\end{tabular}

Valuation of criterion 7 part B - employment deprivation:

\begin{tabular}{lc}
\hline Employment Deprivation & Associated score \\
\hline Well below average JSA claims & 5 \\
Below average JSA claims & 4 \\
Average JSA claims & 3 \\
Above average JSA claims & 2 \\
Well above average JSA claims & 1 \\
\hline
\end{tabular}

*JSA (Job Seekers Allowance)

Accordingly, for this case study the values for criterion 7 part A and part B were calculated as follows (data on the national average JSA claim rate is provided as a benchmark for part A):

\begin{tabular}{cccccc}
\hline \multirow{2}{*}{ Alternative } & \multicolumn{2}{c}{ Criterion 7 part A } & \multicolumn{2}{c}{ Criterion 7 part B } & Final \\
\cline { 2 - 5 } & $\begin{array}{c}\text { JSA } \\
\text { claims }(\%)\end{array}$ & $\begin{array}{c}\text { Associated } \\
\text { score }\end{array}$ & $\begin{array}{c}\text { Access to } \\
\text { employment }\end{array}$ & $\begin{array}{c}\text { Associated } \\
\text { score }\end{array}$ & $\begin{array}{c}\text { value } \\
\text { National average }\end{array}$ \\
\hline .5 & N/A & N/A & N/A & N/A
\end{tabular}




\begin{tabular}{cccccc} 
Princes Park & 12.7 & 1 & High & 3 & 4 \\
Childwall & 3.1 & 4 & High & 3 & 7 \\
Allerton \& Hunts Cross & 3.8 & 2 & High & 3 & 5 \\
\hline
\end{tabular}

Criterion 19 (\% of area in most deprived 10\% nationally) was assessed using the Index of Multiple Deprivation (IMD). The indices of deprivation identify the most disadvantaged areas in England. Deprivation is assessed by examining factors such as income deprivation, health deprivation and disability and barriers to housing and services. To calculate criteria values, Liverpool's average rate of deprivation (\%) was used as a benchmark and each neighbourhood area was compared against it to establish an associated score (see below).

Valuation of criterion 19 - \% of area in most deprived 10\% nationally by IMD (Index of Multiple Deprivation):

\begin{tabular}{lc}
\hline Deprivation & Associated score \\
\hline Well below average IMD & 1 \\
Below average IMD & 2 \\
Average IMD & 3 \\
Above average IMD & 4 \\
Well above average IMD & 5 \\
\hline
\end{tabular}

Accordingly, for this case study the values for criterion 16 were calculated as follows (data on Liverpool is provided as an average benchmark):

\begin{tabular}{ccc}
\hline Alternative & Deprivation rate (IMD \%) & Associated score \\
\hline Liverpool (average benchmark) & 57.9 & N/A \\
Princes Park & 96.4 & 5 \\
Childwall & 5 & 1 \\
Allerton \& Hunts Cross & 39.3 & 2 \\
\hline
\end{tabular}

Following the data collection process a decision-making matrix must be prepared in order to carry out a MCDM assessment. A matrix format easily expresses the MCDM problem [24]. The initial matrix, shown in Table 2, displays the criteria that define sustainable housing affordability, the criteria weights, a set of decision alternatives (residential areas) and criteria values for each alternative. Once the matrix has been created, the values can be processed using a suitable decision making method. 


\subsection{Evaluation of sustainable housing affordability using COPRAS}

Despite the large quantity of MCDM methods available, no single method is considered the most suitable for all types of decision-making situation [32]. Therefore, Guitouni and Martel [32] proposed a conceptual framework for articulating tentative guidelines to choose an appropriate MCDA method. However, it has also been acknowledged that several methods can be potentially valid for a particular decision making situation; there is not always an overwhelming reason to adopt one technique over another [33]. It seems that one of the most important criteria in selecting a MCDM method is its compatibility with the problem's objective [30]. The problem proposed in this study is the assessment of sustainable housing affordability of a number of alternative areas. To determine this, a ranking of alternatives needs to be identified. Therefore, the objective of this problem is to rank alternatives. Consequently, a MCDM method that has the ability to provide a complete ranking of alternatives (indicating the position of each alternative) is required. Additionally, the method must have the ability to handle criteria of both positive and negative influence and those of a quantitative and qualitative nature. Furthermore, ease of use and understanding of the MCDM technique is important so that any interested parties can easily adopt the proposed method.

It was established that COPRAS would be a suitable methodology to adopt for the initial pilot assessment of sustainable housing affordability owing to a number of factors:

- The method is transparent, simple to use and has a low calculation time in comparison with other MCDM methods, such as AHP and TOPSIS [50]. Therefore, this method could easily be adopted by any interested parties.

- COPRAS can provide a complete ranking of alternatives.

- The method can deal with both quantitative and qualitative criteria within one assessment.

- COPRAS has the ability to account for both positive (maximizing) and negative (minimizing) evaluation criteria, which can be assessed separately within the evaluation process. Some basic MCDM methods which could have been applied for this pilot assessment, such as SAW, would require transformation of negative criteria into positive ones, making the procedure more complicated and time consuming for potential users.

- An important feature that makes the COPRAS method superior to other available MCDM methods is that it may be used to estimate the utility degree of alternatives, showing, as a percentage, the extent to which one alternative is better or worse than other alternatives taken for comparison.

- Furthermore, the COPRAS method has been frequently and successfully applied to a range of property, planning and sustainability related problems (highlighted in section 2). 
The COPRAS (COmplex PRoportional ASsessment) method assumes direct and proportional dependence of significance and priority of investigated alternatives on a system of attributes [41]. The significance of the comparative alternatives is determined on the basis of describing positive and negative characteristics of the alternatives. The method estimates the priority order and utility degree of the alternatives.

The COPRAS method is a five-stage procedure [41, 43]:

Stage 1. The first step is in any multi-criteria analysis is normalisation of the decision-making matrix $D$ (Table 3). Normalisation translates data measured with different units - such as points, ratio and percentage - into weighted dimensionless variables, allowing their direct comparison. The following formula is used:

$$
d_{i j}=\frac{q_{i}}{\sum_{j=1}^{n} x_{i j}} \cdot x_{i j}
$$

Where $x_{i j}$ is the value of the $i$-th criterion of the $j$-th alternative, and $q_{i}$ is the weight of the $i$-th criterion. For example, taking the data presented in Table 2 the calculation would be as follows:

$$
d_{21}=\frac{q_{2}}{x_{21}+x_{22}+x_{23}} \cdot x_{21}=\frac{6.37}{25.3+26.7+29.3} \cdot 25.3=2.0
$$

With this transformation, the sum of the dimensionless weighted values $d_{i j}$ of each criterion $x_{i}$ always equals the weight $q_{i}$ of this criterion:

$$
q_{i}=\sum_{j=1}^{n} d_{i j}
$$

For example, looking at the normalised values in Table 3:

$$
q_{1}=d_{11}+d_{12}+d_{13}=1.6+2.2+2.5 \approx 6.37
$$




\section{Table 3 here}

Stage 2: The sums of weighted normalised criteria describing the $j$-th alternative are calculated. The alternatives are described by positive (maximising) criteria $S_{+j}$ and negative (minimising) criteria $S_{-j}$. The higher the positive (maximizing) values are, such as 'quality of housing in area', the better satisfied is sustainable housing affordability. The lower the negative (minimizing) values are, such as 'deprivation in area', the better satisfied is sustainable housing affordability. Sums are calculated according to the formulae:

$$
\begin{aligned}
& S_{j}^{+}=\sum_{z_{i}=+} d_{i j} \\
& S_{j}^{-}=\sum_{z_{i}=-} d_{i j}
\end{aligned}
$$

For example,

$$
S_{3}^{-}=d_{1,3}+d_{2,3}+d_{6,3}+d_{17,3}+d_{19,3}+d_{20,3}=2.5+2.3+0.8+1.1+1.3+2.0=10.0
$$

Stage 3: The significance (priority) of the comparative alternatives is determined on the basis of describing positive $(+)$ and negative (-) qualities that characterise the alternative residential areas. The relative significance $Q_{j}$ of each alternative $A_{j}$ is determined according to: 


$$
Q_{j}=S_{j}^{+}+\frac{S_{\min }^{-} \cdot \sum_{j=1}^{n} S_{j}^{-}}{S_{j}^{-} \cdot \sum_{j=1}^{n} \frac{S_{\min }^{-}}{S_{j}^{-}}}=S_{j}^{+}+\frac{\sum_{j=1}^{n} S_{j}^{-}}{S_{j}^{-} \cdot \sum_{j=1}^{n} \frac{1}{S_{j}^{-}}}
$$

Where $S_{\text {min }}$ - the minimum value of $S_{j}$ - cancels. The first term of $Q_{j}$ increases for higher positive criteria $S_{j}^{+}$, whilst the second term of $Q_{j}$ increases with lower negative criteria $S_{j}$. Thus a higher value of corresponds to more sustainable housing affordability. For example, taking the data considered in Table 3 the significance $Q_{2}$ of $A_{2}$ would be calculated as follows:

$$
Q_{2}=S_{2}^{+}+\frac{S_{1}^{-}+S_{2}^{-}+S_{3}^{-}}{S_{2}^{-} \cdot\left(\frac{1}{S_{1}^{-}}+\frac{1}{S_{2}^{-}}+\frac{1}{S_{3}^{-}}\right)}=22.5+\frac{13.1+7.8+10.0}{7.8 \cdot\left(\frac{1}{13.1}+\frac{1}{7.8}+\frac{1}{10.0}\right)}=35.5
$$

Alternative formulations of $Q_{j}$ are possible. For example, a simple subtraction of the negative criteria leads to the MCDM procedure known as the weighted sum model (WSM):

$$
\bar{Q}_{j}=S_{j}^{+}-S_{j}^{-}
$$

Stage 4: The prioritisation $Q_{j}$ of the alternative residential areas under consideration is determined in this stage. The greater the value $Q_{j}$, the higher the priority (significance) of the alternative. In this case, the significance $Q_{\max }$ of the optimal alternative will always be the highest. From the results displayed in Table 4, we see that the highest $Q_{j}$ value is given by alternative 2 , followed by alternative 3 and alternative 1 .

Stage 5: The final stage is the determination of the alternative that best satisfies sustainable housing affordability. With the increase/decrease of the priority of the analysed alternative, its degree of utility also increases/decreases. The degree of project utility is determined by comparing each analysed alternative with the most efficient one. The residential area that best satisfies the sustainable housing affordability criteria is expressed by the highest degree of utility $N_{j}$ equalling $100 \%$. All utility values related to the considered alternatives will range from $0 \%$ to $100 \%$, between the worst and best alternative out of those under consideration. The degree of utility $N_{j}$ of the alternative $A_{j}$ is determined according to the following formula:

$$
N_{j}=\frac{Q_{j}}{Q_{\max }} \cdot 100 \%
$$

Where $Q_{j}$ and $Q_{\max }$ are significances of the alternatives calculated at stage 4 . For example, taking the data considered in Table 3 the degree of utility $N_{l}$ of $A_{l}$ is calculated as follows:

$$
N_{1}=\frac{Q_{1}}{Q_{\max }} \cdot 100 \%=\frac{30.5}{35.5} \cdot 100 \%=86 \%
$$


The concluding results of stage 2 through to stage 5 of the COPRAS assessment are displayed in Table 4.

\section{Table 4 here}

\section{Results and discussion}

Using the MCDM method COPRAS, an initial assessment of sustainable housing affordability was conducted.. The analysis compared three alternative residential areas in Liverpool, based on 20 weighted decision criteria. Previously there was no criteria system established for assessing sustainable housing affordability. A ranking of the priorities of the residential areas was compiled (Table 5): priority $1=A_{2}$ (Childwall), priority $2=A_{3}$ (Allerton and Hunts Cross), priority $3=A_{1}$ (Princes Park). Therefore, the residential area that best satisfies sustainable housing affordability is $A_{2}$ (Childwall). Of the three areas considered $A_{2}$ (Childwall) did not have the lowest house prices, however after considering all 20 weighted decision criteria it was calculated as the optimal alternative. $A_{1}$ (Princes Park) was determined as the worst performing area. Conversely, if affordability had been assessed exclusively on the basis of housing costs in relation to income then $A_{1}$ would have been prioritised as the most 'affordable' alternative. The results therefore demonstrate how considering additional criteria that better reflect housing quality, location and community sustainability - as opposed to focusing exclusively on housing costs and incomes - can provide a more comprehensive and sustainable analysis of affordability.

An assessment of three housing wards (alternative areas) in Liverpool was made as an example of the MCDM approach; however, the methodology could be applied to all housing wards across the City to assess sustainable housing affordability. The method may also be utilised in other regions. The proposed assessment method would be beneficial for a number of interested parties, such as local authorities, developers and consumers (see Table 5). It would provide local authorities, developers, investors and housing consumers with the information needed to make comprehensive and sustainable decisions about the affordability of housing. The tool could be utilised by local authorities as a potential planning indicator for shaping local housing markets. Developers, local authorities and investors could use the tool to select sites for affordable housing development between competing locations. It would assist in identifying areas that are suitable for affordable housing development, along with areas which may require alternative 
forms of investment to enhance affordability and create attractive and sustainable communities for wider society to reside in. Thus, it could provide and monitor affordable housing development, at the same time promoting sustainable communities and high quality of life. For example, the results concluded that $A_{1}$ (Princes Park) was the worst performing alternative. However, housing costs in this area were lower than the other two areas considered. Accordingly $A_{1}$ (Princes Park) would benefit from improvements to the quality of the location, e.g. reducing crime and deprivation and increasing job opportunities. This area may not be particularly suitable for the development of affordable housing until the quality and sustainability of the community is increased. In comparison $A_{2}$ (Childwall) was calculated to be the optimal alternative. This area would be the most suitable for the development of affordable housing out of the three alternative areas considered as the quality of the location, its access to amenities and facilities, is already high. Identifying appropriate areas for affordable housing development would assist in ensuring high quality of life for sustainable communities. Furthermore, the tool could support housing consumers in making decisions on house purchase, identifying housing locations appropriate to consumers' needs and preferences for criteria.

\section{Table 5 here}

\section{Limitations}

During the study some limitations were encountered. Specifically, the measurement and estimation of criteria values was not possible for the individual residential areas (housing wards) in some instances as sufficient and accessible data was not available. For example, for the valuation of criterion 16 (energy efficiency of housing) 'average SAP ratings' were not available at individual housing ward level, data was only accessible for Liverpool City as a whole. Thus, although the criterion was included into the MCDM calculations it actually had no affect on the final ranking of alternatives as each alternative area had to be given the same value. The same situation occurred with the valuation of criterion 17 (waste management). This was to be measured by the 'percentage of household waste sent for recycling, composting or reuse', but once more data was not available at individual housing ward level, rather it was only obtainable 
for Liverpool City as a whole. The authors suggest that additional data is needed so that such criteria can be more accurately measured at housing ward level and not only for the local authority as a whole. This will allow clearer distinctions to be made between areas regarding their sustainable housing affordability.

\section{Conclusions}

Housing affordability and sustainability are important topics for research which require close cooperation. Assessments of housing affordability must take a broader and more sustainable view of the wide ranging criteria that affect households, including economic, environmental and social aspects. Accordingly this paper has presented a methodology that can be utilised to assess sustainable housing affordability, which is capable of taking into consideration numerous decision criteria. A weighted criteria system - representing sustainable housing affordability was the basis of the assessment method, which was developed by the authors following a recognition that such a criteria system did not previously exist. The MCDM method COPRAS was used for the evaluation and allowed alternative areas to be prioritized in respect of their sustainable housing affordability, based on 20 decision criteria. The paper presented the results of an assessment of three residential areas (housing wards) in Liverpool as an example of the approach. Although applied to Liverpool as a case study, the methodology is generalizeable and could be applied to other regions. The case study data (criteria values) can be changed and computed for other areas.

The MCDM assessment method can assist stakeholders in making more accurate and comprehensive decisions concerning affordability, reflecting the quality and sustainability of a housing location, rather than focusing exclusively on housing costs and incomes. The presented methodology could be adopted by a number of interested parties, including local authorities, governments, developers and investors. The tool could be used on a local, national or international scale. The weighting (importance) of the criteria can be adapted given the requirements of the concerned party and depending on the local situation. Furthermore, the number of alternatives (residential areas) for consideration may be small or large depending on the decision maker's requirements. Furthermore, the presented methodology could be applied to individual housing units, rather than to housing wards (neighbourhood areas). This would allow the affordability of different housing units to be compared and ranked and could assist consumers in making decisions on house purchase.

\section{References}

[1] CLG (Communities and Local Government), Delivering Affordable Housing, CLG, London (2006).

[2] HM Government, Securing the future: delivering UK sustainable development strategy, The Stationery Office, London (2005).

[3] V. Maliene, J. Howe and N. Malys, Sustainable communities: affordable housing and socio-economic relations, Local Economy 23(4) (2008), pp. 267-276.

[4] ODPM (Office of the Deputy Prime Minister), Sustainable Communities: People, Places and Prosperity, The Stationery Office, London (2005).

[5] ODPM (Office of the Deputy Prime Minister), Sustainable communities: Homes for all, The Stationery Office, London (2005). 
[6] N. Winston, Regeneration for Sustainable Communities? Barriers to Implementing Sustainable Housing in Urban Areas, Sustainable Development 18(6) (2010), pp. 319-330.

[7] J. D. Hulchanski, The concept of housing affordability: Six contemporary uses of the housing expenditure-to-income ratio, Housing Studies 10(4) (1995), pp. 471-491.

[8] N. K. Kutty, A New Measure of Housing Affordability: Estimates and Analytical Results, Housing Policy Debate 16(1) (2005), pp. 113-142.

[9] C. Whitehead, S. Monk, A. Clarke, A. Holmans and S. Markkanen, Measuring Housing Affordability: A Re-view of Data Sources, Cambridge Centre for Housing and Planning Research, Cambridge (2009).

[10] E. C. M. Hui, Measuring Affordability in Public Housing from Economic Principles: Case Study of Hong Kong, Journal of Urban Planning and development 127(1) (2001), pp. 34-49.

[11] W. Rea, J. Yuen, J. Engeland and R. Figueroa, The dynamics of housing affordability, Perspectives on Labour and Income 20(1) (2008), pp. 37-48.

[12] M. Robinson, G. M. Scobie and B. Hallinan, Affordability of housing: concepts, measurement and evidence. Working Paper No. 06/03, New Zealand Treasury (2006).

[13] M. E. Stone, Shelter Poverty: New Ideas on Housing Affordability, Temple University Press, Philadelphia (1993).

[14] M. E. Stone, What is housing affordability? The case for the residual income approach, Housing Policy Debate 17(1) (2006), pp. 151-184.

[15] A. S. Bogdon and A. Can, Indicators of Local Housing Affordability: Comparative and Spatial Approaches, Real Estate Economics 25(1) (1997), pp. 43-80.

[16] T. Seelig and P. Phibbs, Beyond the Normative: Low Income Private Renters' Perspectives of Housing Affordability and Need for Housing Assistance, Urban Policy and Research 24(1) (2006), pp. 53-66.

[17] HCCPA (House of Commons Committee of Public Accounts), Housing Market Renewal: Pathfinders Thirty-fifth Report of Session 2007-08, The Stationery Office, London (2008).

[18] Gabriel, M., Jacobs, K., Arthurson, K., Burke, T. and Yates, J. Conceptualising and measuring the housing affordability problem, Research Paper 1, Australian Housing and Urban Research Institute, Melbourne (2005).

[19] J. Yates and V. Milligan, Housing Affordability: A 21st Century Problem, Australian Housing and Urban Research Institute, Melbourne (2007).

[20] CTOD and CNT (Center for Transit-Oriented Development and Center for Neighborhood Technology), The Affordability Index: A New Tool for Measuring the True Affordability of a Housing Choice, Brookings Institution, Washington, DC (2006).

[21] ACF and VCOSS (Australian Conservation Foundation and Victorian Council of Social Service), Housing affordability: More than rents and mortgages, 2008 [online] Available at: vcoss.org.au/documents/VCOSS\%20docs/Housing/REP_ACF_VCOSS\%20Housing\%20Affordabilit y\%20October\%202008\%20.PDF [accessed on $10^{\text {th }}$ July 2010].

[22] L. M. Fisher, H. O. Pollakowski and J. Zabel, Amenity-Based Housing Affordability Indexes, Real Estate Economics 37(4) (2009), pp. 705-746.

[23] C. Zopounidis, Multicriteria decision aid in financial management, European Journal of Operational Research 119 (1999), pp. 404-415.

[24] E. Triantaphyllou, Multi-criteria decision making methods: a comparative study, Kluwer Academic Publishers, Dordrecht (2000).

[25] R. L. Keeney, Value Focused Thinking: A path to Creative Decision Making, Harvard University Press, Cambridge, Massachusetts (1992).

[26] J. Rosenhead, and J. Mingers, J. (Eds.), Rational Analysis in a Problematic World, Wiley, Chichester (2001). 27] T.L. Saaty, The Analytical Hierarchy Process, McGraw-Hill, New York (1980).

[28] C. Hwang and K. Yoon, Multiple Attribute Decision Making, Springer, Berlin (1981).

[29] J.P. Brans, B. Mareschal and P. Vincke, How to select and how to rank projects: The PROMETHEE 
method, European Journal of Operational Research 24(2) (1986), pp. 228-238.

[30] B. Roy, The outranking approach and the foundations of the ELECTRE methods, Theory and Decision 31(1) (1991), pp. 49-73.

[31] E.K. Zavadskas, A. Kaklauskas and V. Sarka, The new method of multicriteria complex proportional assessment of projects, Technological and Economic Development of Economy 1(3) (1994), pp. 131139.

[32] A. Guitouni and J. M. Martel, Tentative Guidelines to Help Choosing an Appropriate MCDA Method, European Journal of Operational Research 109 (1998), pp. 501 - 521.

[33] S. Hajkowicz and A. Higgins, A Comparison of Multiple Criteria Analysis Techniques for Water Resource Management, European Journal of Operational Research 184 (2008), pp. 225 - 265.

[34] S. H. Zanakis, A. Solomon, N. Wishart and S. Dublish, Multi-attribute decision making: a simulation comparison of select methods, European Journal of Operational Research 107(3) (1998), pp. 50729.[35] J. Ball and V. Srinivasan, Using the Analytic Hierarchy Process in House Selection, Real Estate Finance and Economics 9(1) (1994), pp. 69-85.

[36] A. Bender, A. Din, M. Hoesli and S. Brocher, Environmental preferences of homeowners: Further evidence using the AHP method, Journal of Property Investment and Finance 18(4) (2000), pp. 445455.

[37] M.P. Johnson, Spatial decision support for assisted housing mobility counselling, Decision Support Systems 41(1) (2005), pp. 296-312.

[38] E. Natividade-Jesus, J. Coutinho-Rodrigues, and C.H. Antunes, A multicriteria decision support system for housing evaluation, Decision Support Systems 43(3) (2007), pp. 779-790.

[39] S. Lotfi and K. Solaimani, An assessment of Urban Quality of Life by Using Analytic Hierarchy Process Approach (Case study: Comparative Study of Quality of Life in the North of Iran), Journal of Social Sciences 5(2) (2009), pp. 123-133.

[40] E. K. Zavadskas, A. Kaklauskas and N. Kvederyte, Multivariant Design and Multiple Criteria Analysis of a Building Life Cycle, Informatica 12(1) (2001), pp. 169-188.

[41] E. K. Zavadskas, A. Kaklauskas, A. Banaitis and N. Kvederyte, Housing credit access model: The case for Lithuania, European Journal of Operational Research 155(2) (2004), pp. 335-352.

[42] A. Kaklauskas, E.K. Zavadskas and S. Raslanas, Multivariant design and multiple criteria analysis of building refurbishments, Energy and Buildings 37(4) (2005), pp. 361-372.

[43] A. Kaklauskas, E.K. Zavadskas, A. Banaitis and G. Satkauskas, Defining the utility and market value of a real estate: A multiple criteria approach, International Journal of Strategic Property Management 11(2) (2007), pp. 107-120.

[44] M. Viteikiene and E.K. Zavadskas, Evaluating the sustainability of Vilnius City residential areas, Civil Engineering and Management 13(2) (2007), pp. 149-155.

[45] J. Zagorskas, M. Burinskienè, E.K. Zavadskas and Z. Turskis, Urbanistic assessment of city compactness on the basis of GIS applying the COPRAS method, Ekologija 53(Suppl) (2007), pp. $55-63$.

[46] N. Banaitienè, A. Banaitis, A. Kaklauskas and E.K. Zavadskas, Evaluating the life cycle of a building: A multivariant and multiple criteria approach, Omega 36(3) (2008), pp. 429-441.

[47] R. Ginevic rius and V. Podvezko, Evaluating the changes in economic and social development of Lithuanian counties by multiple criteria methods, Technological and Economic Development of Economy 15(3) (2009), pp. 418-436.

[48] L. Uilaityte and V. Martinaitis, Search for optimal solution of public building renovation in terms of life cycle, Journal of Environmental Engineering and Landscape Management 18(2) (2010), pp. 102-110.

[49] M. Medineckiené, Z. Turskis, E.K. Zavadskas and J. Tamošaitienè, Multi-Criteria Selection of the One Flat Dwelling House, Taking into Account the Construction Impact on Environment, in The 10th International Conference Modern Building Materials, Structures and Techniques, Selected papers, Lithuania, Vilnius, (2010), pp. 455-460. 
[50] P. Chatterjee, V. M. Athawale and S. Chakraborty, Materials selection using complex proportional assessment and evaluation of mixed data methods, Materials and Design 32(2) (2011), pp. 851-860.

[51] CLG (Communities and Local Government), Strategic Housing Market Assessments: Practice Guidance Version 2, CLG, London (2007).

[52] C. Whitehead, S. Monk, A. Clarke, A. Holmans and S. Markkanen, Measuring Housing Affordability: A Review of Data Sources, Cambridge Centre for Housing and Planning Research, Cambridge (2009).

[53] NHPAU (National Housing and Planning Advice Unit), Housing affordability: a fuller picture, 2010 [online] Available at: http://www.communities.gov.uk/documents/507390/pdf/14657171.pdf [accessed on $15^{\text {th }}$ February 2010].

[54] Shelter, ROOF Affordability Index 2006, Shelter, London (2006).

[55] V. Maliene and N. Malys, High-quality housing-A key issue in delivering sustainable communities, Building and Environment 44(2) (2009), pp. 426-430.

[56] I. Samuels, What home buyers want: Attitudes and decision making among consumers, Commission for Architecture and the Built Environment (CABE), London (2005).

[57] X. Zhu, S. Liu and M.C.A. Yeow, GIS-Based Multi-Criteria Analysis Approach to Accessibility Analysis for Housing Development in Singapore. In: Proc. of SSC 2005 Spatial Intelligence, Innovation and Praxis: The national biennial Conference of the Spatial Sciences Institute, Melbourne, September 2005.

[58] P. Howley, M. Scott and D. Redmond, Sustainability versus liveability: an investigation of neighbourhood satisfaction, Journal of Environmental Planning and Management 52(6) (2009), pp. 847-864.

[59] M. Jenks, K. Williams and E. Burton, Urban consolidation and the benefits of intensification, in: G. De Roo and D. Miller (Eds) Compact cities and sustainable urban development: A critical assessment of policies and plans from an International perspective, Ashgate Publishing, Aldershot (2000). 
Figure legends

Fig. 1. Map of Liverpool housing wards with case study areas highlighted

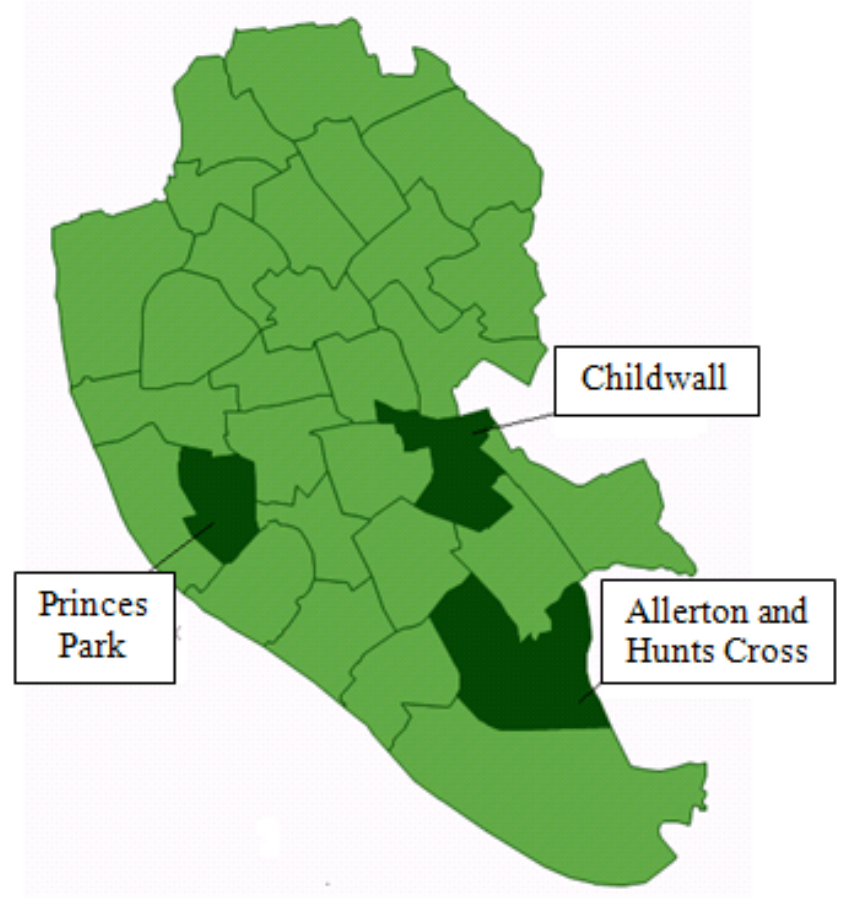




\section{Tables}

Table5. Beneficiaries of research

\begin{tabular}{|c|c|}
\hline $\mathrm{Be}$ & ascecs \\
\hline $\begin{array}{l}\text { Local Authorities, } \\
\text { Housing } \\
\text { Associations and } \\
\text { Government } \\
\text { (local, regional or } \\
\text { international) } \\
\end{array}$ & $\begin{array}{l}\text { - Comprehensive assessment of sustainable housing affordability. } \\
\text { - Assist in making better decisions on house purchase. } \\
\text { - Provide and monitor affordable housing development. } \\
\text { - Promote and maintain high quality of life for sustainable communities. } \\
\text { - Aid in identifying areas which would be suitable for development of } \\
\text { affordable housing and areas which may not be suitable. }\end{array}$ \\
\hline $\begin{array}{l}\text { Developers and } \\
\text { Investors in } \\
\text { affordable housing }\end{array}$ & $\begin{array}{l}\text { - Assist in identifying areas which may require alternative forms of } \\
\text { investment to enhance affordability and create sustainable } \\
\text { communities. } \\
\text { - Use to compare and rank the affordability of different housing } \\
\text { locations. }\end{array}$ \\
\hline $\begin{array}{l}\text { Housing } \\
\text { Consumers and } \\
\text { Wider Society }\end{array}$ & $\begin{array}{l}\text { - Comprehensive assessment of sustainable housing affordability. } \\
\text { - Assist in making better decisions on house purchase. } \\
\text { - Aid in choosing a housing location appropriate to consumers' needs } \\
\text { and preferences for criteria. } \\
\text { - Assist in creating affordable, sustainable and high quality communities } \\
\text { for society to reside in. }\end{array}$ \\
\hline
\end{tabular}


Table 1. Criteria system for sustainable housing affordability and criteria weights

\begin{tabular}{|c|c|c|c|c|}
\hline \multicolumn{2}{|r|}{ Sustainable housing affordability criteria } & \multirow{2}{*}{$\begin{array}{l}\text { Criteria derivation: } \\
\text { Literature } \\
\text { reference/interview } \\
\text { Local authority interview, } \\
{[[51],[52] .}\end{array}$} & \multirow{2}{*}{$\begin{array}{c}\text { Mean } \\
\text { score }\end{array}$} & \multirow{2}{*}{$\begin{array}{c}\text { Weight } \\
\quad q \\
6.35\end{array}$} \\
\hline 1 & House prices in relation to incomes & & & \\
\hline 2 & Rental costs in relation to incomes & $\begin{array}{l}\text { Local authority interview, } \\
{[51],[52] \text {. }}\end{array}$ & 8.69 & 6.37 \\
\hline 3 & Interest rates and mortgage availability & $\begin{array}{l}\text { Local authority interview, } \\
\text { [53], [54]. }\end{array}$ & 7.18 & 5.27 \\
\hline 4 & $\begin{array}{l}\text { Availability of social and private rented } \\
\text { accommodation }\end{array}$ & {$[5],[6],[55]$.} & 7.71 & 5.65 \\
\hline 5 & $\begin{array}{l}\text { Availability of affordable home } \\
\text { ownership products }\end{array}$ & {$[5],[6],[55]$.} & 7.09 & 5.20 \\
\hline 6 & Safety (Crime level) & {$[4],[5],[6],[22]$.} & 6.62 & 4.85 \\
\hline 7 & Access to employment opportunities & {$[4],[5],[6],[22]$.} & 7.49 & 5.49 \\
\hline 8 & Access to public transport services & {$[4],[5],[6],[20],[51]$} & 6.80 & 4.99 \\
\hline 9 & Access to good quality schools & {$[4],[5],[22],[51],[56]$.} & 6.75 & 4.95 \\
\hline 10 & Access to shops & {$[4],[5]$.} & 6.70 & 4.91 \\
\hline 11 & Access to health services & {$[4],[5]$.} & 6.78 & 4.97 \\
\hline 12 & Access to child care & [4], [5]. & 5.42 & 3.97 \\
\hline 13 & Access to leisure facilities & {$[4],[5]$.} & 4.94 & 3.62 \\
\hline 14 & Access to open green public space & $\begin{array}{l}\text { [4], [5], [6], [51], [55], } \\
{[57] .}\end{array}$ & 5.66 & 4.15 \\
\hline 15 & Quality of housing & $\begin{array}{l}\text { Local authority interview, } \\
{[1],[6],[55] .}\end{array}$ & 8.36 & 6.13 \\
\hline 16 & Energy efficiency of housing & $\begin{array}{l}\text { Local authority interview, } \\
{[6],[9],[55] .}\end{array}$ & 7.42 & 5.44 \\
\hline 17 & $\begin{array}{l}\text { Availability of waste management } \\
\text { facilities }\end{array}$ & {$[5],[6],[55]$.} & 4.52 & 3.31 \\
\hline 18 & Desirability of neighborhood area & [58], [59]. & 5.98 & 4.39 \\
\hline 19 & Deprivation in area & {$[2],[4]$.} & 6.89 & 5.05 \\
\hline 20 & $\begin{array}{l}\text { Presence of environmental problems } \\
\text { (e.g. litter, traffic) }\end{array}$ & [4], [6], [55], [58]. & 6.71 & 4.92 \\
\hline
\end{tabular}


Table 2. Initial matrix for MCDM

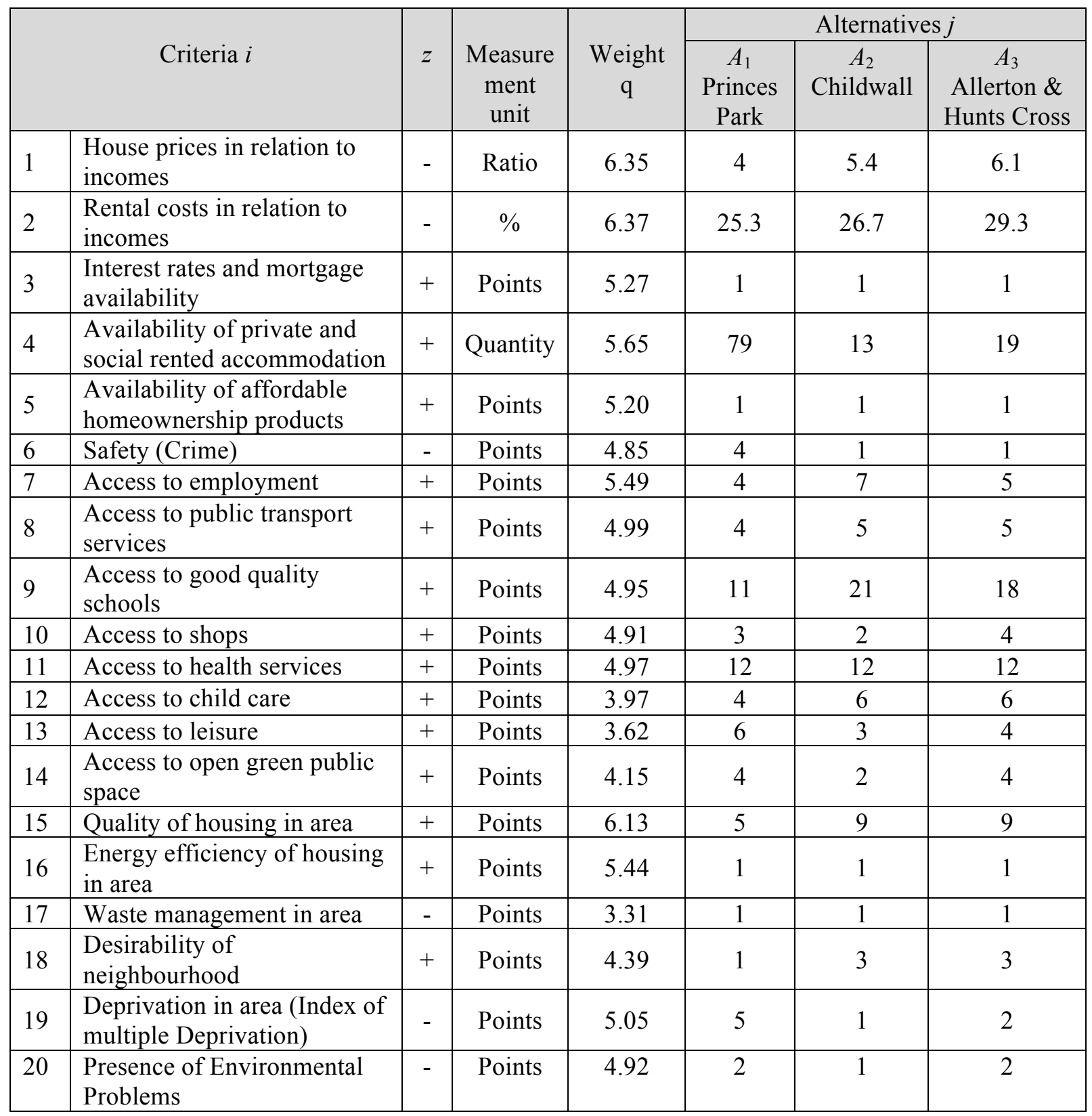

* The sign (+/-) indicates that a greater/lesser criterion value satisfies sustainable housing affordability. 
Table 3. Normalised decision matrix $D$

\begin{tabular}{|c|l|c|c|c|c|}
\hline \multicolumn{2}{|c|}{ Criteria $i$} & \multirow{3}{*}{$z$} & \multicolumn{3}{c|}{ Alternatives $j$} \\
\cline { 3 - 5 } & & $A_{1}$ & $A_{2}$ & $A_{3}$ \\
\hline 1 & House prices in relation to incomes & - & 1.6 & 2.2 & 2.5 \\
\hline 2 & Rental costs in relation to incomes & - & 2.0 & 2.1 & 2.3 \\
\hline 3 & $\begin{array}{l}\text { Interest rates and mortgage } \\
\text { availability }\end{array}$ & + & 1.8 & 1.8 & 1.8 \\
\hline 4 & $\begin{array}{l}\text { Availability of private and social } \\
\text { rented accommodation }\end{array}$ & + & 4.0 & 0.7 & 1.0 \\
\hline 5 & $\begin{array}{l}\text { Availability of affordable } \\
\text { homeownership products }\end{array}$ & + & 1.7 & 1.7 & 1.7 \\
\hline 6 & Safety (Crime) & - & 3.2 & 0.8 & 0.8 \\
\hline 7 & Access to employment & + & 1.4 & 2.4 & 1.7 \\
\hline 8 & Access to public transport services & + & 1.4 & 1.8 & 1.8 \\
\hline 9 & Access to good quality schools & + & 1.1 & 2.1 & 1.8 \\
\hline 10 & Access to shops & + & 1.6 & 1.1 & 2.2 \\
\hline 11 & Access to health services & + & 1.7 & 1.7 & 1.7 \\
\hline 12 & Access to child care & + & 1.0 & 1.5 & 1.5 \\
\hline 13 & Access to leisure & + & 1.7 & 0.8 & 1.1 \\
\hline 14 & Access to open green public space & + & 1.7 & 0.8 & 1.7 \\
\hline 15 & Quality of housing in area & + & 1.3 & 2.4 & 2.4 \\
\hline 16 & $\begin{array}{l}\text { Energy efficiency of housing in } \\
\text { area }\end{array}$ & + & 1.8 & 1.8 & 1.8 \\
\hline 17 & Waste management in area & - & 1.1 & 1.1 & 1.1 \\
\hline 18 & Desirability of neighbourhood area & + & 0.6 & 1.9 & 1.9 \\
\hline 19 & Deprivation in area & - & 3.2 & 0.6 & 1.3 \\
\hline 20 & $\begin{array}{l}\text { Presence of Environmental } \\
\text { Problems }\end{array}$ & - & 2.0 & 1.0 & 2.0 \\
\hline
\end{tabular}

* The sign (+/-) indicates that a greater/lesser criterion value satisfies sustainable housing affordability.

Table 4. Results of COPRAS assessment

\begin{tabular}{|c|c|c|c|}
\hline \multirow{2}{*}{ Criteria $i$} & \multicolumn{3}{|c|}{ Alternatives $j$} \\
\cline { 2 - 4 } & $A_{1}$ & $A_{2}$ & $A_{3}$ \\
\hline$S_{j}^{+}$ & 22.8 & 22.5 & 24.1 \\
\hline$S_{j}$ & 13.1 & 7.8 & 10.0 \\
\hline$Q_{j}$ & 30.5 & 35.5 & 34.2 \\
\hline Priority & 3 & 1 & 2 \\
\hline$N_{j}(\%)$ & 86 & 100 & 96 \\
\hline
\end{tabular}

